\title{
Integrated Application of Mobile-based Raw Material Requests: A Case Study of Head Flour Industry
}

\author{
Harson Kapoh \\ Dept. of Informatic Engineering \\ Manado State Polytechnic \\ Manado 95252 North Sulawesi \\ Indonesia
}

\author{
Olga Melo \\ Dept. of Informatic Engineering \\ Manado State Polytechnic \\ Manado 95252 North Sulawesi \\ Indonesia
}

\author{
Anthon Arie Kimbal \\ Dept. of Informatic Engineering \\ Manado State Polytechnic \\ Manado 95252 North Sulawesi \\ Indonesia
}

\begin{abstract}
In the coconut flour industry, one very basic need for raw material needs is needed. In its implementation there are several important actors in the process to ensure raw materials, approved by the factory, and suppliers. The production process will run well with the available raw materials. Integrated application of raw material requests dedicated to the coconut flour industry to place an order and suppliers in real time will request from the factory. In this study we will formulate an application that integrates demand for raw materials for the mobile-based coconut flour industry. In making the application the method used is the method of developing a waterfall system. With this application, industry players, both factories and suppliers are facilitated in making orders and receiving orders for raw materials.
\end{abstract}

\section{Keywords}

Industry, Application, Mobile, Flour, Coconut

\section{INTRODUCTION}

The coconut flour industry there is one very basic need, namely the need for raw materials. The raw material in question is coconut fruit. It is a necessity in the coconut flour industry, to ensure that raw materials remain at the available level. In its application there are several important actors in the process to ensure raw materials, including the factory and suppliers. Suppliers can be divided into two namely collectors and individual farmers. Currently to place an order from the factory will expect supplies by the way the supplier deliver directly to the factory or the factory will contact the suppliers who are willing. So that it can simply be concluded that the coconut flour factory is highly dependent on suppliers. The production process will run well if raw materials are available[1]. But on the contrary, the production process will be disrupted if the factory does not have the availability of raw materials. This can happen and it is very possible that it has even happened and becomes a problem that often arises in every coconut flour factory. If the factory does not carry out the production process on a day that has actually been projected to be many, of course this is a very serious problem because it can have a direct impact on the factory. The most likely is to experience losses[2].

Technology has become an indisputable need today, as if shifting the needs of the premiere. In this increasingly sophisticated era of mobile applications have been much in favor. Currently, smartphones have become an undeniable major need, including industry players.

At present the Smartphone is no longer an antique. All people even compete to have a smartphone, a smartphone has become a necessity and part of the lifestyle. In the midst of technological developments that increasingly lead to Industry 4.0 with all the existing facilities. Everything is easy with the help of technology, especially mobile technology such as smart phones[3].

Integrated application requests raw materials, answering existing problems. The implementation of this application is utilizing android technology to facilitate the coconut flour industry players. From the factory, it is facilitated to place orders and ensure that raw materials are available every day, so as to minimize the possibility of lack of raw materials to carry out the production process. On the part of the supplier, it would be advantageous to monitor the extent of demand from each factory.

In this study the authors summarize the formulation of the problem that became the subject of discussion How to build an "integrated application of demand for raw materials for the mobile-based coconut flour industry"? and How is the trial of the application? with the aim of building an integrated application for raw material demand, helping the factory to ensure raw materials and helping Suppliers to be able to monitor the demand for raw materials in real time

\section{TEORY}

Java programming language is the basis in Android applications. Java virtual machine (JVM) is a necessity for being able to use an android application. Currently gadged cellular uses an Android software application as an operating system[4].

\section{METHODE}

The method used in this study is a software system development method and testing method.

\subsection{Place and Time}

3.2 This research is universal to what extent this application can be reached and used.

\subsection{Materials and Tools}

Below are the materials and tools used to support the research carried out:

\subsubsection{Materials}

Tabel 1 Materials needed in research

\begin{tabular}{|c|c|c|}
\hline No. & Material name & Description \\
\hline 1. & Android Studio & Main Softwere \\
\hline 2. & Windows $1064-$ Bit & Operation Sistem \\
\hline
\end{tabular}




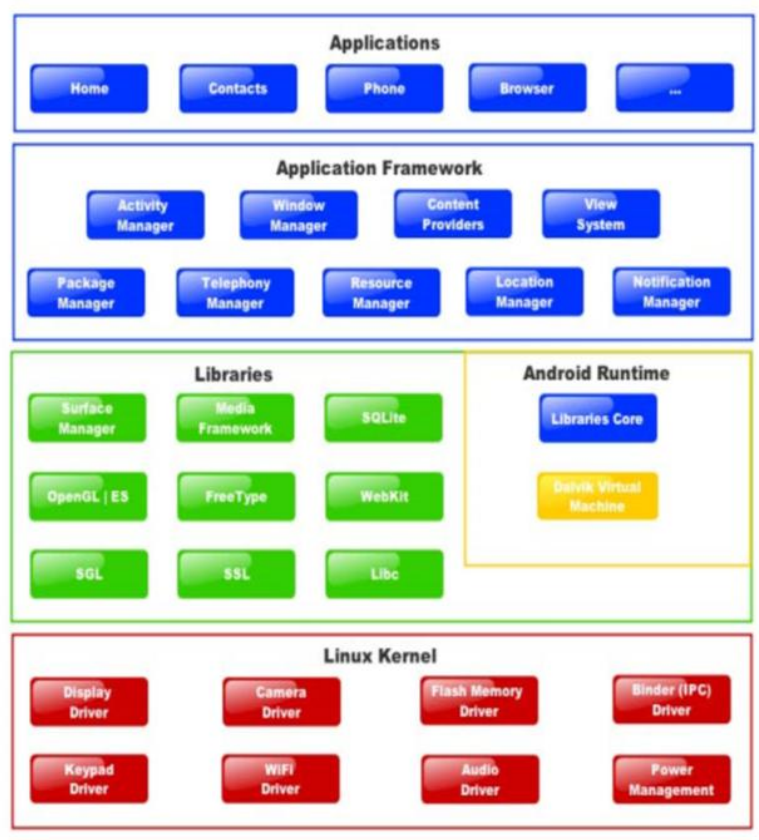

Fig 1. Android Platform Overview

\subsubsection{Tools}

Tabel 2 Tools Needed in Research

\begin{tabular}{|c|c|c|}
\hline No. & Material name & Description \\
\hline 1. & Processor & Laptob \\
\hline
\end{tabular}

\section{DEVELOPMENT}

The design method that will be used for the research planning plan is not limited but more or less includes the following sections.

\subsection{Research Procedure}

Below are listed several research procedures that the author uses to support this research:

\subsubsection{Research Methods and Types}

The methods and types of research that the authors adopt or use are as follows:

\subsubsection{Metode Waterfall}

In this study the authors used the Waterfall System Development Method, and below are the steps[4]:

\section{Requirement Definition}

In this study the authors took one sample of coconut flour factory. The place where the writer took the sample is PT. Royal Coconut, Airmadidi. The author did get into trouble as already described in "Background". Furthermore, the authors discuss the design of the system from this application made.

\section{System Design}

In this process, allocating needs - existing needs to the hardware or software by making the overall system architecture. Software design involves identifying and explaining the system abstrack and its relationship

\section{Implementation}

This stage of software design is realized in the form of program units. Unit testing aims to ensure that each unit of the program is made according to its specifications.
4. Integration \& Testing

Program units are tested as a whole system to ensure that all specifications are met.

\section{Operation \& Maintenance}

This stage does not have to be done, but it is a stage that is sometimes very necessary to develop and requires the longest time. Maintenance includes repairing errors that were not found in previous stages, repairing the system and making the system better to meet new specifications. Maintenance of the software reapplies each phase before, then fixes the previous program and does not create a new one.

\subsubsection{Conceptual framework of design}

Since this conceptual framework is a very important part, it is important to be able to determine the right design as well. Following the design of this application:

\subsubsection{System Design}

Below are some of the modeling used in building this application

\subsubsection{Use Case Diagram}

Figure 1 can be seen that in this system has 3 actors namely, factories, collectors and farmers. Figure 1. explains the features that can be accessed by each actor.

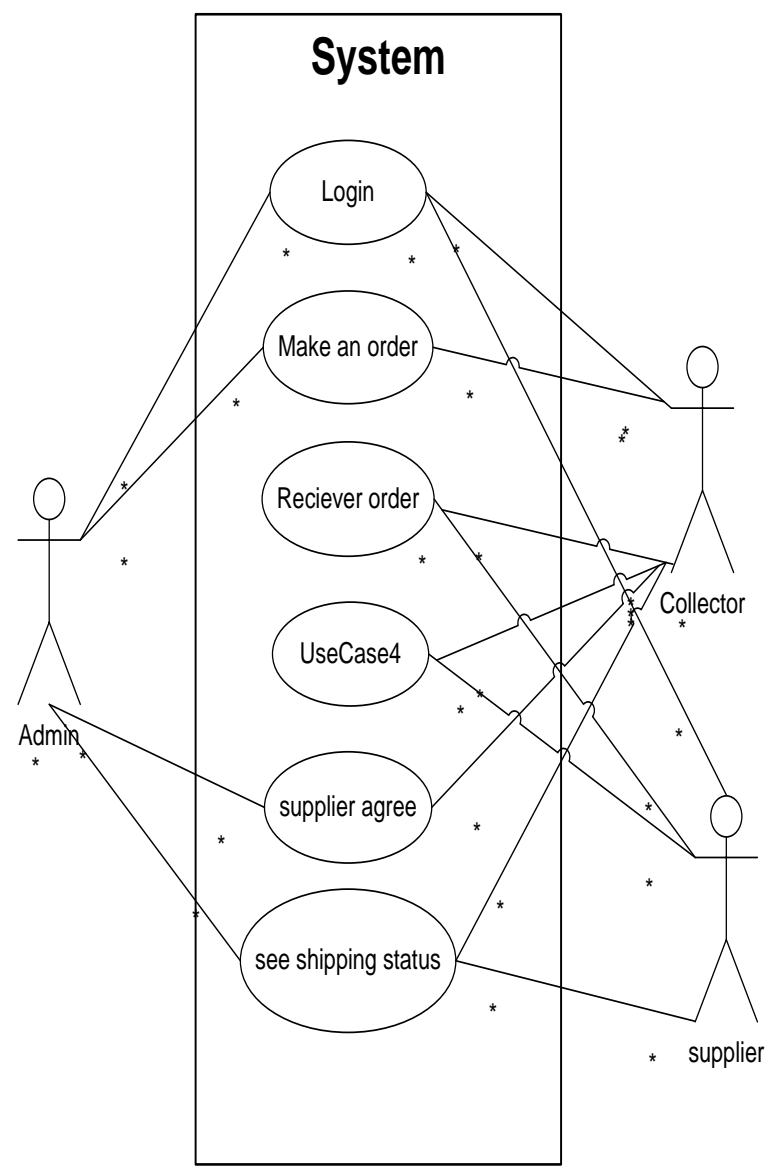

Fig 1: Usecase diagram apllication 
Tabel 3 Use Case Diagram Aplikasi

\begin{tabular}{|c|c|c|}
\hline Actor & Feature & Description \\
\hline Factory & $\begin{array}{c}\text { 1. Login } \\
\text { 2. Make an Order } \\
\text { 3.Approve the Supplier } \\
\text { 4.View Delivery Status }\end{array}$ & $\begin{array}{l}\text { 1.Login to the } \\
\text { Application } \\
\text { 2.Making Orders To } \\
\text { Suppliers } \\
\text { 3.Approve the bid } \\
\text { submitted by the } \\
\text { supplier } \\
\text { 4.Delivery Status of } \\
\text { Raw Materials from } \\
\text { the Supplier }\end{array}$ \\
\hline $\begin{array}{c}\text { Collect } \\
\text { or }\end{array}$ & $\begin{array}{c}\text { 1. Login } \\
\text { 2. Make an Order } \\
\text { 3. Receiving Orders } \\
\text { 4. Submitting an Offer } \\
\text { 5. Approve Supplier } \\
\text { 6. Delivery Status }\end{array}$ & $\begin{array}{l}\text { 1.Login into the } \\
\text { application } \\
\text { 2.Making orders to } \\
\text { farmers } \\
\text { 3. Receive orders from } \\
\text { the factory } \\
\text { 4. Submitting Offer To } \\
\text { The Factory } \\
\text { 5.Approve the Offer of } \\
\text { the Committee } \\
\text { 6.Current status of raw } \\
\text { materials shipped }\end{array}$ \\
\hline $\begin{array}{l}\text { The } \\
\text { Farmer }\end{array}$ & $\begin{array}{c}\text { 1. Login } \\
\text { 2. Receiving Orders } \\
\text { 3. Submitting an Offer } \\
\text { 4. Delivery Status }\end{array}$ & $\begin{array}{l}\text { 1.Login into the } \\
\text { application } \\
\text { 2.Receiving orders } \\
\text { from factories and } \\
\text { collectors } \\
\text { 3.Submitting Raw } \\
\text { Material Offers to } \\
\text { Suppliers } \\
\text { 4.Current status of raw } \\
\text { materials shipped }\end{array}$ \\
\hline
\end{tabular}

\subsubsection{Flowchart}

Below, the author includes a Flowchart or sequence of processes which is also temporarily applied by most industry players, in this case coconut flour factories in obtaining raw materials.

The system implemented is waiting for suppliers to supply raw materials. When raw materials arrive at the factory, they will be checked whether the supplier is registered at the factory or not. If you have not already then it is required to carry out the registration process by providing information related to the supplier. If it has been registered it will proceed to the process according to the flowchart above. This process is considered by the writer to open up opportunities that raw materials are not available. Surely the factory can not estimate that there are suppliers who will provide the supply of raw materials or not. And it was proven when the writer conducted the survey process in one of the factories that was found like that. And when there is no raw material, the production process stops (see Figure 2)

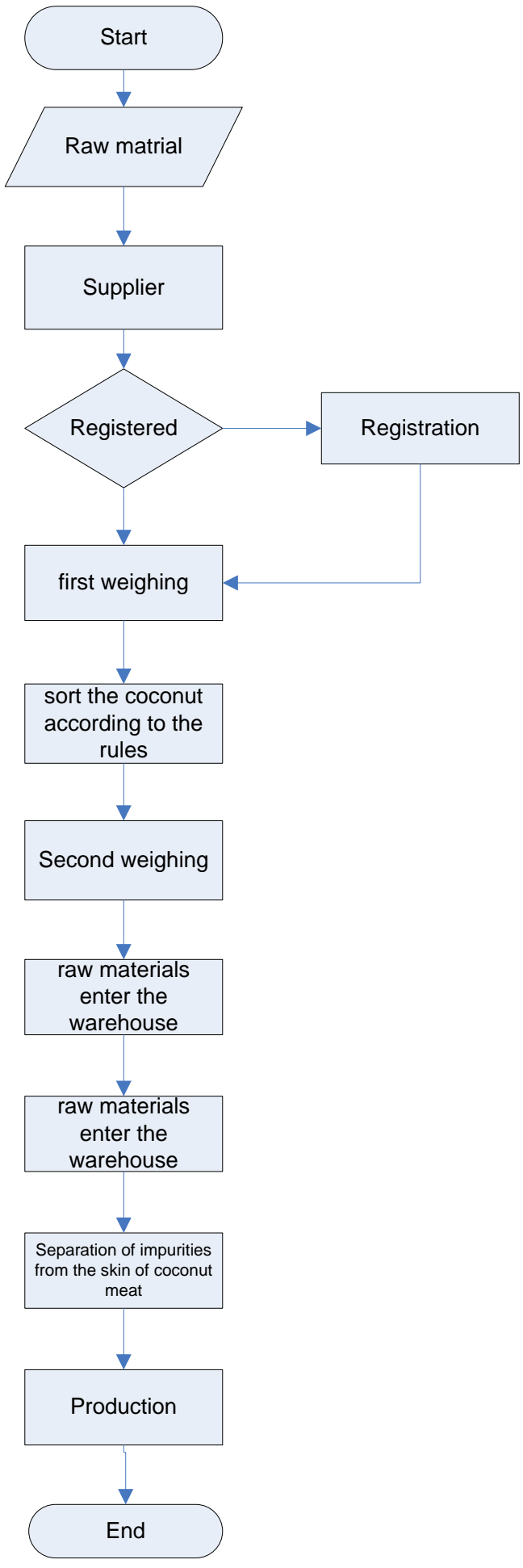

Fig 2: Current system

The flowchart above is an overview of the applications made in this study. Simply put, this application can be an alternative factory for finding raw materials. This application can guarantee that raw materials are always available because the demand for raw materials is published through the application and later will be seen in real time by the suppliers. This application also makes it possible for distant suppliers to find out the raw material requirements of the factory (see Figure $3)$. 


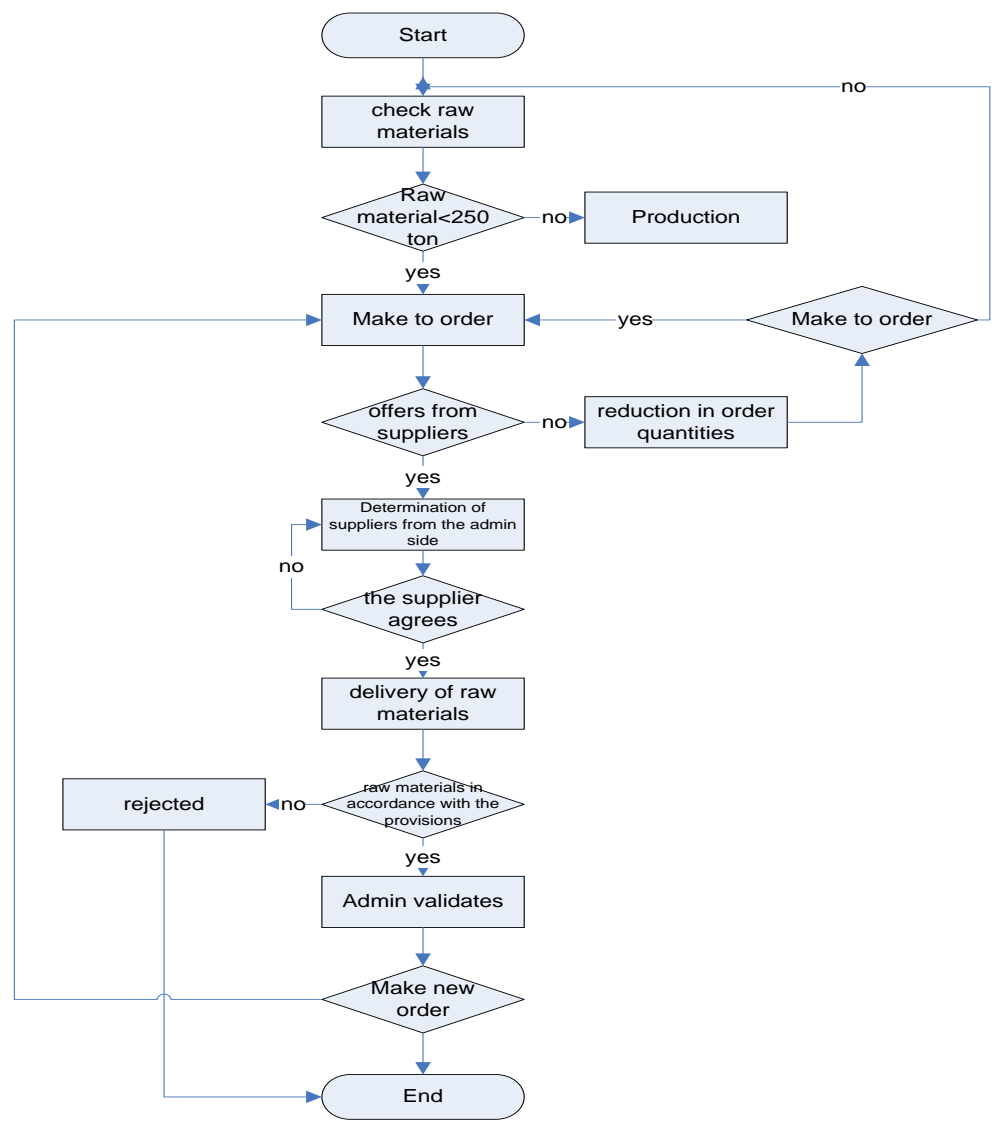

Fig 3: The system used in this study

To $\log$ in to the application, users are of course required to enter a username and password. Then the system will check whether the database or username already exists. If it is not available then the next action is to register of course to continue. If available, the system will direct users to the main page in the application.

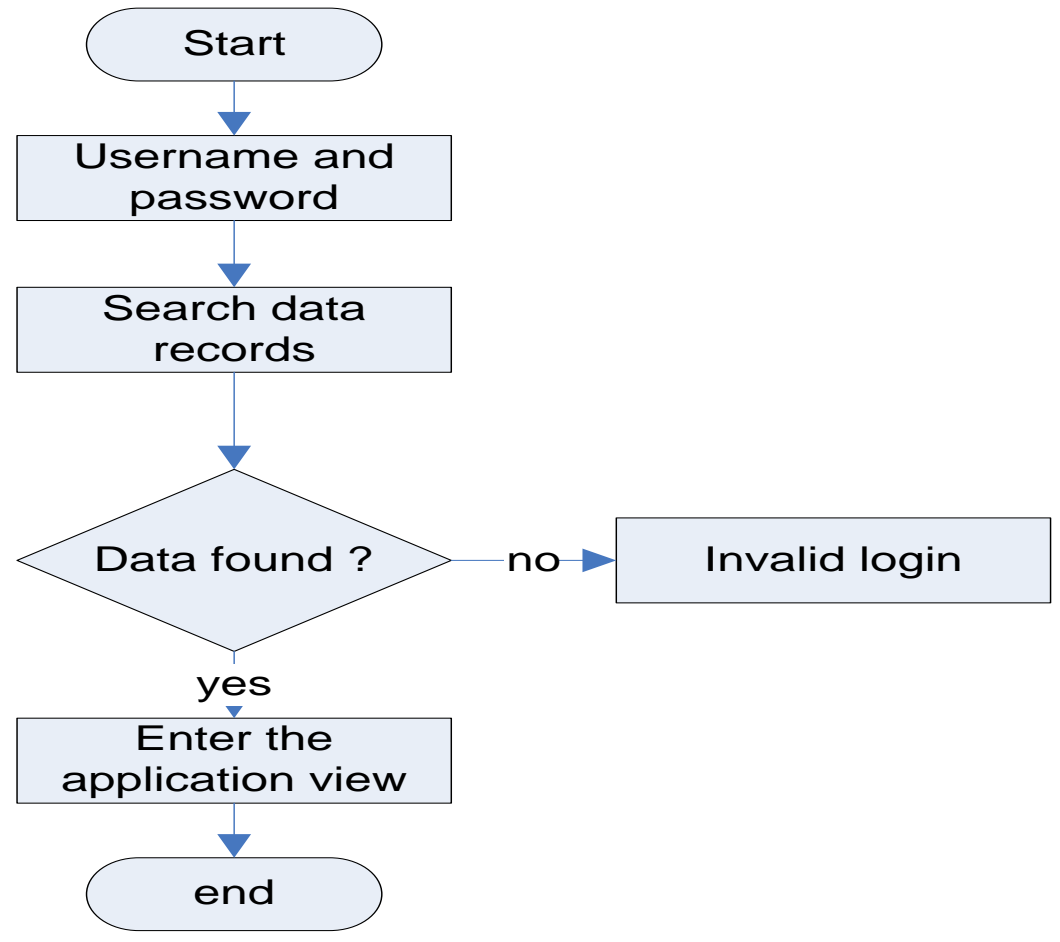

Fig 4: Flowchart Login 
To register, users are required to enter some data in it Username, Password, user name, No. Telephone, NPWP, No. Account, Address, then choose as what.

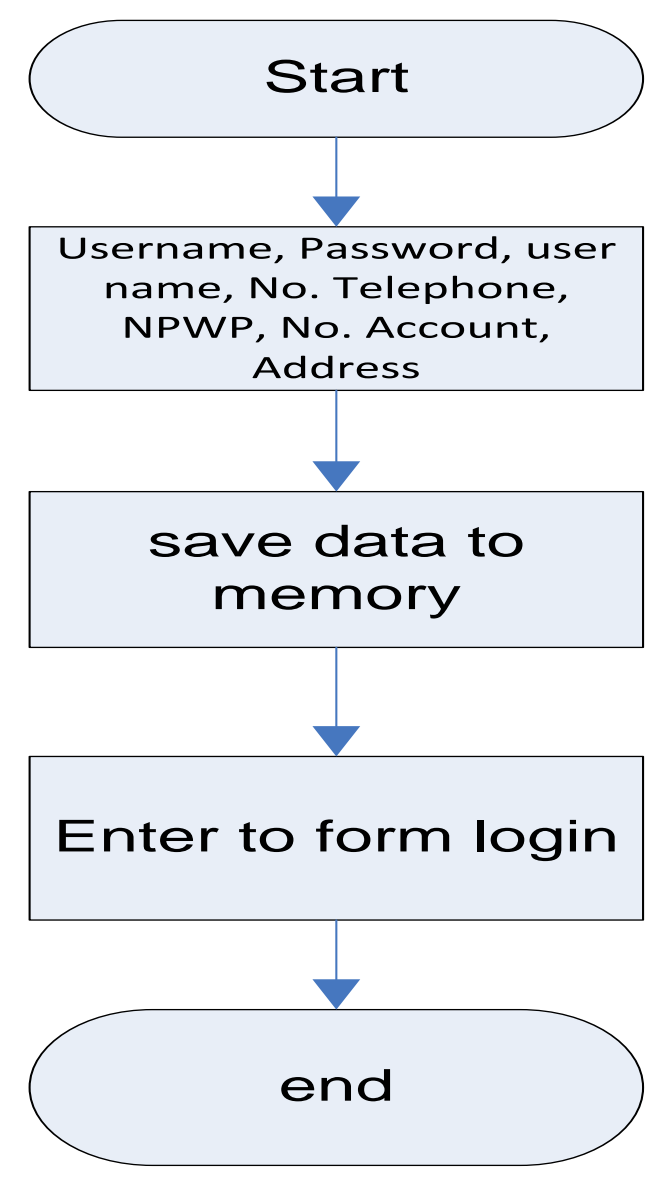

Fig 5: Registration Flowchart

\subsubsection{Activity Diagram}

In this study the authors also use activity diagrams to be able to facilitate how the system runs by covering from the admin, factory and supplier. Suppliers intended here are collectors and farmers.

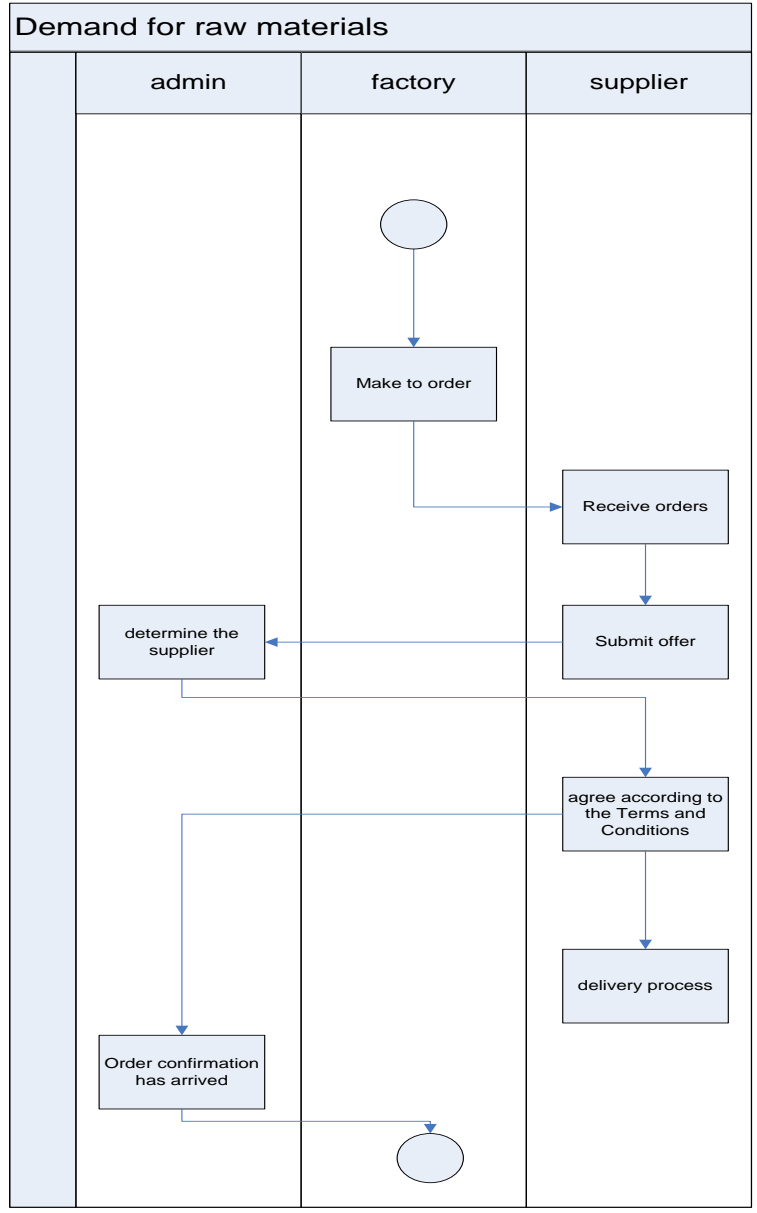

Fig 6: Activity Diagram of the System

\section{RESULT}

Some of the interfaces of the development program are as follows:

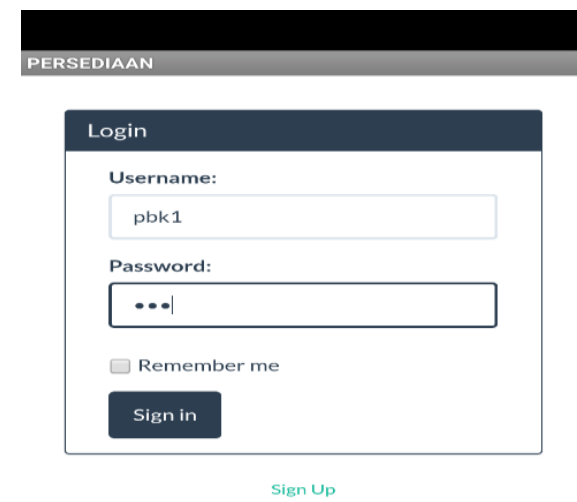

Fig 7: Login page 


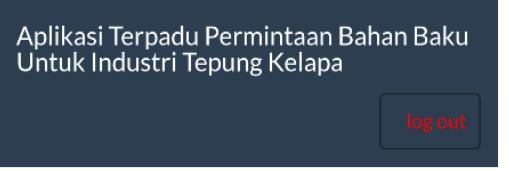

DI SETUJUI PABRIK

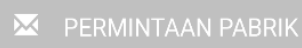

2 PROFIL

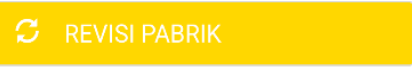

1 PENAWARAN PABRIK

* tidak DI SetujuI PabriK

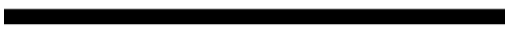

Fig 8: Main Page of the factory
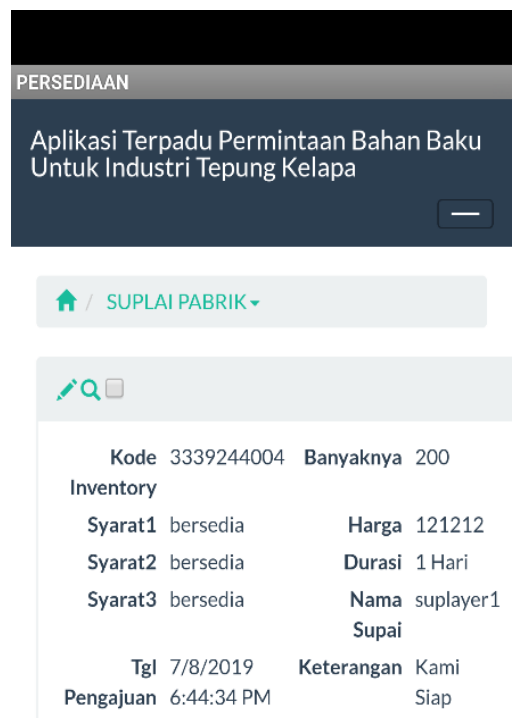

@Copyrights 2019

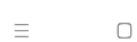

Fig 9: Supplier Pages That Offer

\section{TESTING}

Testing using the black box method

Table 4. Testing Login to the Application

\begin{tabular}{|c|c|c|c|c|}
\hline No. & $\begin{array}{l}\text { Data } \\
\text { Input }\end{array}$ & Expected Data & $\begin{array}{c}\text { Observati } \\
\text { on }\end{array}$ & $\begin{array}{c}\text { Inform } \\
\text { ation }\end{array}$ \\
\hline 1. & $\begin{array}{c}\text { Username } \\
\& \\
\text { Password }\end{array}$ & $\begin{array}{l}\text { Can enter the } \\
\text { application with } \\
\text { the specified } \\
\text { category when } \\
\text { registered }\end{array}$ & $\begin{array}{c}\text { Can enter } \\
\text { with no } \\
\text { problems }\end{array}$ & $\begin{array}{c}\text { Successf } \\
\text { ul }\end{array}$ \\
\hline 2. & Sign In & $\begin{array}{c}\text { Button Can } \\
\text { deliver to the } \\
\text { home page of } \\
\text { the user if it is } \\
\text { already } \\
\text { registered }\end{array}$ & $\begin{array}{c}\text { The } \\
\text { function } \\
\text { of the } \\
\text { Sign in } \\
\text { button is } \\
\text { going well } \\
\text { and can } \\
\text { log into } \\
\text { the } \\
\text { applicatio } \\
n\end{array}$ & $\begin{array}{c}\text { Successf } \\
\text { ully }\end{array}$ \\
\hline
\end{tabular}

\section{CONCLUCION}

Manual work system with examples that have been described in this study, this application can also be used to ensure the availability of raw materials in the following days. So that the factory is facilitated for the availability of raw materials in the future and the supplier can directly monitor in real time through the application when there is a request from the factory.

\section{ACKNOWLEDGMENTS}

Thank you to the leadership and research center of Manado State Polytechnic.

\section{REFERENCES}

[1] H. Kapoh, O. Melo, A. A. Kimbal and A. Polii, "Model Transaction of Raw Material for Coconut Fruit On North Sulawesi Coconut Flour Industry," 2018 International Conference on Applied Science and Technology (iCAST), Manado, Indonesia, 2018, pp. 200-204.

[2] Kapoh, Harson, Edwin Stephanus Lumunon, and Olga Melo. "Material Requirement Model of Coconut Flour Production and Performance Testing based Multi User in North Sulawesi." International Journal of Computer Applications 152.7 (2016).

[3] A. G. Parada and L. B. d. Brisolara, "A Model Driven Approach for Android Applications Development," 2012 Brazilian Symposium on Computing System Engineering, Natal, 2012, pp. 192-197.

[4] doi: 10.1109/SBESC.2012.44

[5] Vincent, Karl \& Joy, Jessa \& Ann, Charry \& G., Hanzrick. (2019). A Mobile-Assisted Learning Application of Mother Tongue for Grade 3. International Journal of Computer Applications. 178. 15-18. 10.5120/ijca2019918949. 